\title{
KOMPETENSI GURU REGULER DI SEKOLAH INKLUSIF DALAM PEMBELAJARAN BAGI SISWA TUNARUNGU
}

\author{
Murni Winarsih \\ e-mail: winarsih.murni@yahoo.com \\ Pendidikan Luar Biasa FIP UNJ
}

\begin{abstract}
Abstrak: Penelitian ini bertujuan untuk mengetahui kompetensi guru reguler dalam melakukan proses pembelajaran kepada siswa tunarungu di sekolah penyelenggara pendidikan inklusif. Penelitian ini dilaksanakan pada Februari 2012 sampai dengan Juni 2013. Penelitian ini menggunakan metode deskriptif kualitatif, dengan teknik pengumpulan data melalui wawancara, observasi, dan telaah dokumen kepada 5 orang guru di 5 sekolah inklusif. Temuan dalam penelitian ini adalah guru di sekolah inklusif belum memiliki kemampuan dalam melakukan pembelajaran kepada siswa tunarungu. Guru reguler selama ini juga belum pernah mengikuti pelatihan yang secara khusus membahas tentang pembelajaran tunarungu dikarenakan belum adanya paket pelatihan pembelajaran tunarungu berbasis contextual learning. Penelitian ini menghasilkan beberapa implikasi dan saran.
\end{abstract}

Kata kunci: pendidikan inklusif, pembelajaran tunarungu, contextual learning

\section{REGULER TEACHER COMPETENCE OF LEARNING IN INCLUSIVE SCHOOLS FOR DEAF STUDENTS}

\begin{abstract}
The aim of this study is to explore the teachers's competency in teaching students with hearing impairments within inclusive educational settings. This research conducted from February 2012 through June 2013. Method of the research is qualitative descriptive, observation and interview were employed to gather the necessary data towards 5 teachers where there is at least one student with hearing impairment in their classroom across all educational level. The result shows that the teachers do not have the competency about teaching the hearing impairments. The teachers have never been trained on teaching and instruction of children with hearing impairment, because the training based on contextual learning has not been previous. The research results some implication and recomendation.
\end{abstract}

Keywords: inclusive education, teaching the hearing impairment, contextual learning

\section{PENDAHULUAN}

Sistem pendidikan di Indonesia saat ini sudah memudahkan siswa berkebutuhan khusus untuk memilih tempat mendapatkan pendidikan yang layak. Hal ini didukung oleh layanan Sistem Penerimaan Peserta Didik Baru (PPDB) secara online yang memberikan prioritas khusus bagi siswa-siswa berkebutuhan khusus untuk masuk ke sekolah reguler. Sistem pendidikan yang menerima siswa berkebutuhan khusus ini dikenal dengan pendidikan inklusif, se perti yang dikemukakan oleh Tarmansyah (2007: 82), bahwa sekolah harus mengakomodasi semua siswa tanpa memandang kondisi fisik, intelektual, sosial emosional, linguistik atau kondisi lainnya.

Sekolah inklusif semestinya sudah menyiapkan komponen pendukung termasuk sarana dan prasarana sebagai bukti bahwa sudah siapnya pihak sekolah untuk menerima siswa dengan kebutuhan khusus. Termasuk di dalamnya adalah guru yang akan mengajar kelas di mana siswa berkebutuhan khusus belajar bersama siswa lain di dalamnya. Maka guru reguler yang dimaksud dalam penelitian ini adalah guru yang mengajar di sekolah penyelenggara pendidikan inklusif dan tidak memiliki latar belakang Pendidikan Luar Biasa (PLB). Guru-guru ini berasal dari berbagai rumpun pendidikan baik dari jurusan kependidikan maupun non kependidikan. Tanpa memiliki bekal mengenai karakteristik siswa berkebutuhan khusus, namun para guru harus menerima siswa berkebutuhan khusus tersebut untuk turut belajar dalam kelas yang diajarnya karena berada di sekolah yang ditunjuk 
sebagai penyelenggara pendidikan inklusif, maka mau tidak mau guru-guru harus mengajar semua siswa yang ada di dalamnya sesuai kurikulum yang ditetapkan dan menjadi acuan dalam melakukan pembelajaran, sehingga praktis kompetensi guru-guru tersebut belum memadai dikarenakan belum dikuasainya ilmu ke-PLB-an.

Kompetensi menurut Usman (2009: 14) adalah suatu hal yang menggambarkan kualifikasi atau kemampuan seseorang, baik yang kualitatif maupun kuantitatif. Kemampuan kualitatif seseorang adalah kemampuan sikap dan perbuatan seseorang yang hanya dapat dinilai dengan ukuran baik dan buruk. Sedangkan kuantitatif adalah kemampuan seseorang yang dapat dinilai dengan ukuran (terukur).

Pada satu sisi sistem pendidikan inklusif ini menguntungkan bagi siswa $A B K$, namun di sisi yang lain sistem ini menyulitkan bagi guru reguler, dikarenakan guru belum memiliki pengetahuan dan keterampilan dalam membelajarkan siswa ABK. Keadaan ini mengakibatkan siswa ABK terlihat tidak dididik sesuai kebutuhannya dan siswa ABK dibiarkan terlantar.

Siswa ABK yang masuk ke sekolah reguler terdiri dari semua jenis kelainan, termasuk siswa tunarungu. Siswa tunarungu menurut Morees sebagimana dikutip oleh Winarsih (2007: 22) mengemukakan bahwa siswa tunarungu adalah siswa yang mengalami hambatan pendengaran ringan hingga sangat berat, yang berdampak kepada kemampuan berbahasa dan berkomunikasi. Interaksi dan komunikasi yang tidak efektif antara siswa tunarungu dengan guru, dan siswa tunarungu dengan siswa lainnya yang mendengar, mengakibatkan hasil belajar siswa tunarungu tidak optimal.

Dalam proses pembelajaran siswa tunarungu tidak menggunakan media visual yang dapat membantu dalam memahami materi pelajaran yang diberikan oleh guru, siswa juga masih mendapatkan metode yang disamakan seperti siswa yang mendengar, yaitu menggunakan metode ceramah, serta evaluasi yang diberikan guru untuk siswa tunarungu juga masih sama dengan siswa lainnya dimana guru tidak memperhatikan bentuk soal dan penggunaan bahasa bagi siswa tunarungu.

Berdasarkan uraian tersebut maka artikel ini akan membahas hasil penelitian yang menjawab pertanyaan tentang, Bagaimana kompetensi guru di sekolah inklusif dalam melakukan pembelajaran bagi siswa tunarungu?

\section{METODE PENELITIAN}

Penelitian ini dilakukan mulai bulan Februari 2012 hingga Juni 2013, bertempat di Sekolah penyelenggara pendidikan inklusif di wilayah DKI Jakarta. Penelitian ini menggunakan metode deskriptif kualitatif, teknik pengumpulan data melalui observasi, wawancara, dan telaah dokumen. Observasi dilakukan untuk melihat kenyataan di lapangan bagaimana guru melaksanakan pembelajaran bagi siswa tunarungu di sekolah inklusif. Sebagai penguat hasil observasi dilakukan wawancara terhadap guru di sekolah inklusif dari jenjang pendidikan dasar hingga pendidikan menengah atas. Observasi dan wawancara menggali hal-hal tentang: (1) pendidikan inklusif, (2) karakteristik ABK, (3) program pembelajaran individual, (4) strategi pembelajaran siswa tunarungu di kelas inklusif. Untuk mengetahui apakah proses pelaksanaan pembelajaran bagi siswa tunarungu sudah sesuai dengan teori belajar dan prinsip-prinsip pembelajaran, maka dilakukan telaah dokumen yang dimiliki guru. Dokumen yang ditelaah adalah berupa silabus dan RPP. 


\section{HASIL DAN PEMBAHASAN}

\section{Hasil Penelitian}

Penelitian ini menghasilkan temuan yang dibuat sintesis yaitu sebagai berikut.

Tabel 1. Sintesis Hasil Penelitian

\begin{tabular}{|c|c|c|c|c|c|c|}
\hline \multirow{2}{*}{ Aspek } & \multirow{2}{*}{ Indikator } & \multicolumn{5}{|c|}{ Kesimpulan } \\
\hline & & R 1 & R 2 & R 3 & R 4 & R 5 \\
\hline \multirow[t]{2}{*}{$\begin{array}{l}\text { Menguasai } \\
\text { karakteristik } \\
\text { peserta didik }\end{array}$} & $\begin{array}{l}\text { Menjelaskan karak- } \\
\text { teristik peserta } \\
\text { didik yang berkai- } \\
\text { tan dengan aspek } \\
\text { fisik, intelektual, } \\
\text { sosial emosional, } \\
\text { dan latar belakang } \\
\text { sosial budaya }\end{array}$ & $\begin{array}{l}\text { Belum memahami } \\
\text { karakteristik siswa } \\
\text { tunarungu yang } \\
\text { ada di kelasnya }\end{array}$ & $\begin{array}{l}\text { Belum memaha- } \\
\text { mi karakteristik } \\
\text { siswa tunarungu } \\
\text { yang ada di } \\
\text { kelasnya }\end{array}$ & $\begin{array}{l}\text { Belum memaha- } \\
\text { mi karakteristik } \\
\text { siswa tunarun- } \\
\text { gu yang ada di } \\
\text { kelasnya }\end{array}$ & $\begin{array}{l}\text { Belum mema- } \\
\text { hami karak- } \\
\text { teristik siswa } \\
\text { tunarungu } \\
\text { yang ada di } \\
\text { kelasnya }\end{array}$ & $\begin{array}{l}\text { Sudah mene- } \\
\text { mpatkan siswa } \\
\text { tunarungu di } \\
\text { posisi depan }\end{array}$ \\
\hline & $\begin{array}{l}\text { Mengidentifikasi } \\
\text { kesulitan peserta } \\
\text { didik dalam proses } \\
\text { pembelajaran }\end{array}$ & $\begin{array}{l}\text { Melakukan iden- } \\
\text { tifikasi kesulitan } \\
\text { siswa namun } \\
\text { masih bersifat } \\
\text { subyektif }\end{array}$ & $\begin{array}{l}\text { Melakukan iden- } \\
\text { tifikasi kesulitan } \\
\text { siswa namun } \\
\text { masih bersifat } \\
\text { subyektif }\end{array}$ & $\begin{array}{l}\text { Sudah mampu } \\
\text { mengidentifi- } \\
\text { kasi saat proses } \\
\text { pembelajaran } \\
\text { berlangsung }\end{array}$ & $\begin{array}{l}\text { Melakukan } \\
\text { identifikasi } \\
\text { kesulitan } \\
\text { siswa namun } \\
\text { masih bersifat } \\
\text { subyektif }\end{array}$ & $\begin{array}{l}\text { Melakukan iden- } \\
\text { tifikasi kesulitan } \\
\text { siswa namun } \\
\text { masih bersifat } \\
\text { subyektif }\end{array}$ \\
\hline \multirow[t]{2}{*}{$\begin{array}{l}\text { Menguasai } \\
\text { teori-teori } \\
\text { belajar dan } \\
\text { prinsip- prin- } \\
\text { sip pembela- } \\
\text { jaran }\end{array}$} & $\begin{array}{l}\text { Menggunakan ber- } \\
\text { bagai teori belajar } \\
\text { dan prinsip-prinsip } \\
\text { pembelajaran yang } \\
\text { mendidik yang } \\
\text { terkait dengan } \\
\text { berbagai bidang } \\
\text { pengembangan }\end{array}$ & $\begin{array}{l}\text { Tidak menggu- } \\
\text { nakan metode } \\
\text { yang bervariasi }\end{array}$ & $\begin{array}{l}\text { Tidak menggu- } \\
\text { nakan metode } \\
\text { yang bervariasi } \\
\text { tetapi memberi- } \\
\text { kan kesempatan } \\
\text { kepada peserta } \\
\text { didik untuk } \\
\text { lebih mengerti }\end{array}$ & $\begin{array}{l}\text { Tidak menggu- } \\
\text { nakan metode } \\
\text { yang bervariasi } \\
\text { tetapi memberi- } \\
\text { kan kesempatan } \\
\text { kepada peserta } \\
\text { didik untuk } \\
\text { lebih mengerti }\end{array}$ & $\begin{array}{l}\text { Sudah } \\
\text { menggu- } \\
\text { nakan metode } \\
\text { yang berva- } \\
\text { riasi tetapi } \\
\text { untuk siswa } \\
\text { tunarungu } \\
\text { menggunakan } \\
\text { metode pem- } \\
\text { belajaran yang } \\
\text { sama dengan } \\
\text { yang tidak } \\
\text { tunarungu }\end{array}$ & $\begin{array}{l}\text { Metode tidak } \\
\text { bervariasi }\end{array}$ \\
\hline & $\begin{array}{l}\text { Menerapkan } \\
\text { berbagai pendeka- } \\
\text { tan, strategi, dan } \\
\text { metode yang ber- } \\
\text { sifat holistik dalam } \\
\text { pembelajaran }\end{array}$ & $\begin{array}{l}\text { Tidak menerapkan } \\
\text { strategi pembelaja- } \\
\text { ran yang holistik }\end{array}$ & $\begin{array}{l}\text { Tidak mener- } \\
\text { apkan strategi } \\
\text { pembelajaran } \\
\text { yang holistik }\end{array}$ & $\begin{array}{l}\text { Tidak mener- } \\
\text { apkan strategi } \\
\text { pembelajaran } \\
\text { yang holistic }\end{array}$ & $\begin{array}{l}\text { Tidak mener- } \\
\text { apkan strategi } \\
\text { pembelajaran } \\
\text { yang holistik }\end{array}$ & $\begin{array}{l}\text { Tidak mener- } \\
\text { apkan strategi } \\
\text { pembelajaran } \\
\text { yang holistik }\end{array}$ \\
\hline \multirow[t]{3}{*}{$\begin{array}{l}\text { Mengem- } \\
\text { bangkan } \\
\text { kurikulum }\end{array}$} & $\begin{array}{l}\text { Memahami } \\
\text { prinsip-prinsip } \\
\text { pengembangan } \\
\text { kurikulum } \\
\end{array}$ & Sudah menguasai & $\begin{array}{l}\text { Sudah mengua- } \\
\text { sai }\end{array}$ & $\begin{array}{l}\text { Sudah men- } \\
\text { guasai }\end{array}$ & $\begin{array}{l}\text { Sudah men- } \\
\text { guasai }\end{array}$ & Sudah menguasai \\
\hline & $\begin{array}{l}\text { Membuat perenca- } \\
\text { naan pembelajaran }\end{array}$ & $\begin{array}{l}\text { Sudah membuat } \\
\text { RPP tapi belum } \\
\text { membuat PPI }\end{array}$ & $\begin{array}{l}\text { Sudah membuat } \\
\text { RPP tapi belum } \\
\text { membuat PPI }\end{array}$ & $\begin{array}{l}\text { Sudah membuat } \\
\text { RPP tapi belum } \\
\text { membuat PPI }\end{array}$ & $\begin{array}{l}\text { Sudah mem- } \\
\text { buat RPP tapi } \\
\text { belum mem- } \\
\text { buat PPI }\end{array}$ & $\begin{array}{l}\text { Sudah membuat } \\
\text { RPP tapi belum } \\
\text { membuat PPI }\end{array}$ \\
\hline & $\begin{array}{l}\text { Memilih materi } \\
\text { pembelajaran yang } \\
\text { sesuai dengan } \\
\text { tujuan }\end{array}$ & $\begin{array}{l}\text { Materi masih } \\
\text { disamakan dengan } \\
\text { anak mendengar }\end{array}$ & $\begin{array}{l}\text { Materi masih } \\
\text { disamakan } \\
\text { dengan anak } \\
\text { mendengar } \\
\end{array}$ & $\begin{array}{l}\text { Materi masih } \\
\text { disamakan } \\
\text { dengan anak } \\
\text { mendengar } \\
\end{array}$ & $\begin{array}{l}\text { Materi masih } \\
\text { disamakan } \\
\text { dengan anak } \\
\text { mendengar } \\
\end{array}$ & $\begin{array}{l}\text { Materi masih dis- } \\
\text { amakan dengan } \\
\text { anak mendengar }\end{array}$ \\
\hline \multirow[t]{2}{*}{$\begin{array}{l}\text { Menyeleng- } \\
\text { garakan } \\
\text { kegiatan } \\
\text { pembelajaran }\end{array}$} & $\begin{array}{l}\text { Memahami prin- } \\
\text { sip-prinsip pembe- } \\
\text { lajaran yang sesuai } \\
\text { dengan karakteris- } \\
\text { tik peserta didik }\end{array}$ & $\begin{array}{l}\text { Belum menguasai } \\
\text { prinsip pembela- } \\
\text { jaran bagi siswa } \\
\text { tunarungu }\end{array}$ & $\begin{array}{l}\text { Belum mengua- } \\
\text { sai prinsip pem- } \\
\text { belajaran bagi } \\
\text { siswa tunarungu }\end{array}$ & $\begin{array}{l}\text { Belum men- } \\
\text { guasai prinsip } \\
\text { pembelajaran } \\
\text { bagi siswa } \\
\text { tunarungu }\end{array}$ & $\begin{array}{l}\text { Belum men- } \\
\text { guasai prinsip } \\
\text { pembelajaran } \\
\text { bagi siswa } \\
\text { tunarungu }\end{array}$ & $\begin{array}{l}\text { Belum menguasai } \\
\text { prinsip pembela- } \\
\text { jaran bagi siswa } \\
\text { tunarungu }\end{array}$ \\
\hline & $\begin{array}{l}\text { Mengembangkan } \\
\text { komponen-kom- } \\
\text { ponen kegiatan } \\
\text { pembelajaran }\end{array}$ & $\begin{array}{l}\text { Mampu mengem- } \\
\text { bangkan kom- } \\
\text { ponen pembela- } \\
\text { jaran }\end{array}$ & $\begin{array}{l}\text { Mampu } \\
\text { mengembang- } \\
\text { kan komponen } \\
\text { pembelajaran }\end{array}$ & $\begin{array}{l}\text { Mampu } \\
\text { mengembang- } \\
\text { kan komponen } \\
\text { pembelajaran }\end{array}$ & $\begin{array}{l}\text { Mampu } \\
\text { mengem- } \\
\text { bangkan } \\
\text { komponen } \\
\text { pembelajaran }\end{array}$ & $\begin{array}{l}\text { Mampu mengem- } \\
\text { bangkan kom- } \\
\text { ponen pembela- } \\
\text { jaran }\end{array}$ \\
\hline
\end{tabular}




\begin{tabular}{|c|c|c|c|c|c|c|}
\hline \multirow{2}{*}{ Aspek } & \multirow{2}{*}{ Indikator } & \multicolumn{5}{|c|}{ Kesimpulan } \\
\hline & & R 1 & R 2 & R 3 & R 4 & R 5 \\
\hline & $\begin{array}{l}\text { Menerapkan kegia- } \\
\text { tan pembelajaran } \\
\text { bersifat holistik } \\
\text { dan bermakna }\end{array}$ & $\begin{array}{l}\text { Hanya berpusat } \\
\text { pada guru dengan } \\
\text { menggunakan } \\
\text { metode ceramah }\end{array}$ & $\begin{array}{l}\text { Hanya berpu- } \\
\text { sat pada guru } \\
\text { dengan menggu- } \\
\text { nakan metode } \\
\text { ceramah }\end{array}$ & $\begin{array}{l}\text { Mampu meli- } \\
\text { batkan peserta } \\
\text { didik }\end{array}$ & $\begin{array}{l}\text { Belum meli- } \\
\text { batkan peserta } \\
\text { didik }\end{array}$ & $\begin{array}{l}\text { Hanya berpusat } \\
\text { pada guru dengan } \\
\text { menggunakan } \\
\text { metode ceramah }\end{array}$ \\
\hline & $\begin{array}{l}\text { Menciptakan } \\
\text { suasana kegiatan } \\
\text { pembelajaran } \\
\text { yang menyenang- } \\
\text { kan, inklusif, dan } \\
\text { demokratis }\end{array}$ & $\begin{array}{l}\text { Guru belum } \\
\text { melakukan } \\
\text { pembelajaran } \\
\text { yang menyenang- } \\
\text { kan, inklusif dan } \\
\text { demokratis bagi } \\
\text { peserta didik }\end{array}$ & $\begin{array}{l}\text { Guru belum } \\
\text { melakukan pem- } \\
\text { belajaran yang } \\
\text { menyenangkan, } \\
\text { inklusif dan } \\
\text { demokratis bagi } \\
\text { peserta didik }\end{array}$ & $\begin{array}{l}\text { Sudah mampu } \\
\text { melakukan } \\
\text { pembela- } \\
\text { jaran yang } \\
\text { menyenangkan, } \\
\text { inklusif dan } \\
\text { demokratis bagi } \\
\text { peserta didik }\end{array}$ & $\begin{array}{l}\text { Guru belum } \\
\text { melakukan } \\
\text { pembela- } \\
\text { jaran yang } \\
\text { menyenang- } \\
\text { kan dan } \\
\text { nyaman bagi } \\
\text { peserta didik }\end{array}$ & $\begin{array}{l}\text { Guru belum } \\
\text { melakukan pem- } \\
\text { belajaran yang } \\
\text { menyenangkan } \\
\text { dan nyaman bagi } \\
\text { peserta didik }\end{array}$ \\
\hline & $\begin{array}{l}\text { Memanfaatkan } \\
\text { media dan sumber } \\
\text { belajar yang sesuai } \\
\text { dengan pendekat- } \\
\text { an pembelajaran }\end{array}$ & $\begin{array}{l}\text { Belum meman- } \\
\text { faatkan media dan } \\
\text { sumber belajar } \\
\text { yang sesuai }\end{array}$ & $\begin{array}{l}\text { Belum meman- } \\
\text { faatkan media } \\
\text { dan sumber } \\
\text { belajar yang } \\
\text { sesuai }\end{array}$ & $\begin{array}{l}\text { Belum meman- } \\
\text { faatkan media } \\
\text { dan sumber } \\
\text { belajar yang } \\
\text { sesuai }\end{array}$ & $\begin{array}{l}\text { Sudah me- } \\
\text { manfaatkan } \\
\text { media dan } \\
\text { sumber belajar } \\
\text { yang sesuai }\end{array}$ & $\begin{array}{l}\text { Belum meman- } \\
\text { faatkan media dan } \\
\text { sumber belajar } \\
\text { yang sesuai }\end{array}$ \\
\hline \multirow[t]{2}{*}{$\begin{array}{l}\text { Memanfaat- } \\
\text { kan teknologi } \\
\text { informasi dan } \\
\text { komunikasi }\end{array}$} & $\begin{array}{l}\text { Memanfaatkan TIK } \\
\text { untuk meningkat- } \\
\text { kan kualitas kegia- } \\
\text { tan pembelajaran }\end{array}$ & Belum & Belum & Belum & Sudah & Belum \\
\hline & $\begin{array}{l}\text { Mampu menggu- } \\
\text { nakan TIK }\end{array}$ & Belum & Belum & Belum & Sudah & Belum \\
\hline $\begin{array}{l}\text { Memfasilitasi } \\
\text { pengemban- } \\
\text { gan potensi } \\
\text { peserta didik }\end{array}$ & $\begin{array}{l}\text { Menyediakan } \\
\text { berbagai kegiatan } \\
\text { pembelajaran } \\
\text { untuk mengaktu- } \\
\text { alisasikan potensi } \\
\text { peserta didik, } \\
\text { termasuk kreativi- } \\
\text { tasnya }\end{array}$ & Belum & Belum & Belum & Belum & Belum \\
\hline \multirow[t]{2}{*}{$\begin{array}{l}\text { Mampu ber- } \\
\text { komunikasi } \\
\text { secara efektif } \\
\text { dengan peser- } \\
\text { ta didik }\end{array}$} & $\begin{array}{l}\text { Menjelaskan berb- } \\
\text { agai strategi ber- } \\
\text { komunikasi yang } \\
\text { efektif, empatik, } \\
\text { dan santun secara } \\
\text { lisan, tulisan, atau } \\
\text { bentuk lain }\end{array}$ & Belum & $\begin{array}{l}\text { Sudah tapi } \\
\text { sedikit }\end{array}$ & Sudah terampil & Sedikit & Sudah tapi sedikit \\
\hline & $\begin{array}{l}\text { Menerapkan } \\
\text { bentuk-bentuk } \\
\text { komunikasi sesuai } \\
\text { dengan karakter- } \\
\text { istik peserta didik } \\
\text { secara efektif }\end{array}$ & $\begin{array}{l}\text { Hanya komunikasi } \\
\text { lisan }\end{array}$ & $\begin{array}{l}\text { Hanya komuni- } \\
\text { kasi lisan tetapi } \\
\text { dengan gerak } \\
\text { bibir yang jelas } \\
\text { dan isyarat } \\
\text { alamiah }\end{array}$ & $\begin{array}{l}\text { Hanya komuni- } \\
\text { kasi lisan tetapi } \\
\text { dengan gerak } \\
\text { bibir yang jelas } \\
\text { dan isyarat } \\
\text { alamiah }\end{array}$ & $\begin{array}{l}\text { Hanya komu- } \\
\text { nikasi lisan } \\
\text { tetapi dengan } \\
\text { gerak bibir } \\
\text { yang jelas } \\
\text { dan isyarat } \\
\text { alamiah }\end{array}$ & $\begin{array}{l}\text { Hanya komuni- } \\
\text { kasi lisan tetapi } \\
\text { dengan gerak bi- } \\
\text { bir yang jelas dan } \\
\text { isyarat alamiah }\end{array}$ \\
\hline \multirow[t]{2}{*}{$\begin{array}{l}\text { Menyeleng- } \\
\text { garakan } \\
\text { penilaian dan } \\
\text { evaluasi }\end{array}$} & $\begin{array}{l}\text { Memahami } \\
\text { prinsip-prinsip } \\
\text { penilaian dan } \\
\text { evaluasi proses dan } \\
\text { hasil belajar sesuai } \\
\text { dengan karakteris- } \\
\text { tik pelajaran }\end{array}$ & $\begin{array}{l}\text { Evaluasi berben- } \\
\text { tuk pilihan ganda } \\
\text { dan uraian }\end{array}$ & $\begin{array}{l}\text { Evaluasi berben- } \\
\text { tuk pilihan gan- } \\
\text { da dan uraian }\end{array}$ & $\begin{array}{l}\text { Evaluasi ber- } \\
\text { bentuk pilihan } \\
\text { ganda dan } \\
\text { uraian }\end{array}$ & $\begin{array}{l}\text { Evaluasi } \\
\text { diambil dari } \\
\text { LKS dan ber- } \\
\text { bentuk pilihan } \\
\text { ganda dan } \\
\text { uraian }\end{array}$ & $\begin{array}{l}\text { Evaluasi berben- } \\
\text { tuk pilihan ganda } \\
\text { dan uraian }\end{array}$ \\
\hline & $\begin{array}{l}\text { Mengembang- } \\
\text { kan instrumen } \\
\text { penilaian dan } \\
\text { evaluasi proses dan } \\
\text { hasil belajar }\end{array}$ & $\begin{array}{l}\text { Belum mengem- } \\
\text { bangkan untuk } \\
\text { siswa tunarungu }\end{array}$ & $\begin{array}{l}\text { Belum mengem- } \\
\text { bangkan untuk } \\
\text { siswa tunarungu }\end{array}$ & $\begin{array}{l}\text { Belum mengem- } \\
\text { bangkan untuk } \\
\text { siswa tunarun- } \\
\text { gu }\end{array}$ & $\begin{array}{l}\text { Belum } \\
\text { mengem- } \\
\text { bangkan } \\
\text { untuk siswa } \\
\text { tunarungu }\end{array}$ & $\begin{array}{l}\text { Belum mengem- } \\
\text { bangkan untuk } \\
\text { siswa tunarungu }\end{array}$ \\
\hline $\begin{array}{l}\text { Memanfaat- } \\
\text { kan hasil } \\
\text { penilaian } \\
\text { dan evalu- } \\
\text { asi untuk } \\
\text { kepentingan } \\
\text { pembelajaran }\end{array}$ & $\begin{array}{l}\text { Menggunakan } \\
\text { informasi hasil } \\
\text { penilaian dan } \\
\text { evaluasi untuk } \\
\text { menentukan ketun- } \\
\text { tasan belajar }\end{array}$ & $\begin{array}{l}\text { Hanya berdasar- } \\
\text { kan KKM }\end{array}$ & $\begin{array}{l}\text { Hanya berdasar- } \\
\text { kan KKM }\end{array}$ & $\begin{array}{l}\text { Hanya ber- } \\
\text { dasarkan KKM }\end{array}$ & $\begin{array}{l}\text { Hanya } \\
\text { berdasarkan } \\
\text { KKM }\end{array}$ & $\begin{array}{l}\text { Hanya berdasar- } \\
\text { kan KKM }\end{array}$ \\
\hline
\end{tabular}




\begin{tabular}{|c|c|c|c|c|c|c|}
\hline \multirow{2}{*}{ Aspek } & \multirow{2}{*}{ Indikator } & \multicolumn{5}{|c|}{ Kesimpulan } \\
\hline & & R 1 & R 2 & R 3 & R 4 & R 5 \\
\hline $\begin{array}{l}\text { Melakukan } \\
\text { tindakan re- } \\
\text { flektif untuk } \\
\text { peningkatan } \\
\text { kualitas pem- } \\
\text { belajaran }\end{array}$ & $\begin{array}{l}\text { Melakukan refleksi } \\
\text { terhadap pembe- } \\
\text { lajaran yang telah } \\
\text { dilaksanakan }\end{array}$ & Tidak & $\begin{array}{l}\text { Melakukan } \\
\text { dalam bentuk } \\
\text { kesimpulan }\end{array}$ & $\begin{array}{l}\text { Melakukan } \\
\text { dengan cara } \\
\text { menanyakan } \\
\text { materi yang su- } \\
\text { dah dipelajari }\end{array}$ & Tidak & Tidak \\
\hline \multirow{2}{*}{$\begin{array}{l}\text { Melakukan } \\
\text { kegiatan un- } \\
\text { tuk mening- } \\
\text { katkan } \\
\text { kompetensi } \\
\text { pedagogik }\end{array}$} & $\begin{array}{l}\text { Kegiatan pelatihan } \\
\text { pengembangan diri } \\
\text { terkait pembela- } \\
\text { jaran }\end{array}$ & Belum & $\begin{array}{l}\text { Pernah mengi- } \\
\text { kuti pelatihan } \\
\text { tentang ABK } \\
\text { secara umum }\end{array}$ & Belum & Belum & Belum \\
\hline & $\begin{array}{l}\text { Bentuk-bentuk ke- } \\
\text { giatan yang terkait } \\
\text { dengan kompetensi } \\
\text { pedagogic }\end{array}$ & Belum & Belum & Belum & Belum & Belum \\
\hline
\end{tabular}

\section{Pembahasan}

Pembahasan hasil penelitian ini akan dijabarkan berdasarkan temuan dari indikator instrumen sebagai berikut.

Pada umumnya ke 5 responden sudah mampu melakukan identifikasi tetapi masih bersifat subyektif, hal ini disebabkan karena para responden belum mampu mengenali karakteristik siswa tunarungu secara benar. Contoh identifikasi yang bersifat subyektif yaitu guru menilai siswa tunarungu berdasarkan kebiasaan yang dimunculkan oleh siswa saat berkomunikasi yang kurang merespon, cenderung diam dan masa bodoh. Guru juga mendapatkan informasi tentang ketunarunguan siswa dari teman sebayanya di sekolah. Dari ke-5 responden hanya ada satu yang sudah memahami karakteristik sehingga menempatkan siswa tunarungu duduk di bangku paling depan agar tidak terhalang oleh posisi duduk teman lainnya.

Pada aspek penguasaan teori-teori belajar dan prinsip-prinsip pembelajaran hanya ada 1 responden yang sudah menggunakan metode yang bervariasi dalam mengajar di kelas inklusif, yaitu dengan menggunakan metode diskusi dan presentasi. Dalam diskusi kelompok, siswa tunarungu dilibatkan sebagai penyaji dan siswa tunarungu juga mampu mempresentasikan hasil diskusi kelompoknya, di sini terlihat responden memberikan kesempatan dan memberi kepercayaan kepada siswa tunarungu. Namun semua responden belum menerapkan berbagai pendekatan, strategi, dan metode yang bersifat holistik dalam pembelajaran khususnya untuk siswa tunarungu. Responden melakukan pembelajaran dengan strategi yang biasa digunakan untuk siswa mendengar.

Pada aspek pengembangan kurikulum semnua responden sudah mampu membuat silabus dan RPP sesuai dengan ketentuan yang berlaku, tetapi semua responden belum membuat program pembelajaran individual yang semestinya dibuat untuk siswa berkebutuhan khusus yang ada di sekolah inklusif khususnya dalam hal ini siswa tunarungu. Bagi sekolah inklusif dalam memberikan pembelajaran kepada siswa berkebutuhan khusus harus sesuai dengan karakteristik belajar siswa tunarungu, hal ini sesuai dengan Permendiknas nomor 70 tahun 2009 pasal 8. Tidak dibuatnya PPI oleh semua responden dikarenakan responden belum mengetahui adanya peraturan terseut dan 4 dari 5 sekolah inklusif belum memiliki Guru Pembimbing Khusus (GPK).

Untuk aspek penyelenggaraan pembelajaran di kelas inklusif semua responden belum menggunakan prinsip-prinsip pembelajaran yang khusus bagi siswa tunarungu, seperti keterarahwajahan, keterarahsuaraan, penggunaan visualisasi dan menggunakan benda-benda konkrik sebagai pendukung dalam proses pembelajaran. Responden belum membuat materi yang berbeda untuk siswa tunarungu, materi untuk siswa tunarungu seharusnya disederhanakan dari segi bahasanya dan jika terlampau sulit materi bisa dibuat lebih fleksibel sesuai kemampuan siswa tunarungu, sedangkan dalam penggunaan media hanya satu responden yang sudah menggunakan media visual berupa power point yang dapat membantu pembelajaran bagi siswa tunarungu, dan hanya satu responden yang sudah mampu memanfaatkan teknologi informasi untuk meningkatkan kualitas pembelajaran. Pembelajaran yang dirancang oleh semua responden hanya sebatas pembelajaran di dalam kelas saja. Sedangkan dari 5 responden hanya 1 responden yang sudah menciptakan suasana kegiatan pembelajaran yang menyenangkan, inklusif, dan demokratis. Hal ini disebabkan responden tidak memiliki kompetensi yang memadai untuk mengembangkan pembelajaran dengan TIK .

Aspek dalam melakukan evaluasi, semua re- 
sponden membuatnya dalam bentuk pilihan ganda dan uraian, dan 1 responden masih mengandalkan soal-soal evaluasi yang ada dalam Lembar Kerja Siswa (LKS) tanpa membuat sendiri, hal ini tentu tidak menguntungkan bagi siswa tunarungu yang memiliki keterbatasan dalam berbahasa, seharusnya evaluasi untuk siswa tunarungu didesain khusus sesuai dengan kemampuan bahasa yang sudah dimilikinya. Evaluasi yang diberikan juga masih berdasarkan kriteria ketuntasan minimal yang ditetapkan oleh sekolah masing-masing saja dan tidak memperhatikan keberadaan siswa tunarungu di kelas tersebut. Untuk aspek pelaporan hasil evaluasi, selama ini semua responden hanya menginformasikan saat pembagian rapot tiap semester. Sehingga guru belum dapat memberikan bantuan bagi yang masih mengalami kesuliatan dan mendapatkan hasil belajar tidak maksimal sesuai KKM sekolah.

Untuk aspek komunikasi, semua responden hanya sedikit melakukan komunikasi dengan siswa tunarungu dan terbatas pada komunikasi lisan saja, belum ammpu untuk menggunakan bahasa isyarat yang baku (Sistem Isyarat Bahasa Indonesia), hanya sebatas isyarat alamiah saja, tentu hal ini merugikan bagi siswa tunarungu, karena kebutuhan komunikasi sangat penting dan membantu siswa dalam meningkatkan kualitas belajar di kelas.

Pelatihan-pelatihan yang ada selama ini hanya sebatas sosialisasi saja, tanpa adanya unsur praktik yang secara langsung dapat membantu pelaksanaan pembelajaran. Tidak adanya pelatihan yang berbasis contextual learning yaitu bentuk pelatihan yang mengedepankan praktik dan pembelajaran yang sesuai dengan kondisi sebenarnya, seperti yang dikemukakan oleh Sagala (2005: 88) bahwa Contextual learning atau belajar kontekstual adalah sebuah sistem yang mendorong siswa untuk membangun keterkaitan, independensi, relasi-relasi penuh makna antara apa yang dipelajari dengan realitas, lingkungan personal, sosial dan kultural yang terjadi sekarang ini. Pengertian lain yaitu strategi belajar siswa yang menggunakan konstruktivisme sebagai basis teori, belajar kontekstual berusaha memfasilitasi siswa untuk menemukan dan memberi makna atas rangsangan dan pengalaman yang diperolehnya dalam belajar sehingga dia mampu untuk memberdayakan dirinya.

Belajar akan lebih bermakna jika siswa "mengalami" apa yang dipelajarinya bukan "mengetahuinya". Pembelajaran yang berorientasi pada target penguasaan materi telah terbukti berhasil dalam "mengingat" jangka pendek, namun gagal membekali siswa dalam memecahkan persoalan pada kehidupan jangka panjang. Pendekatan kontekstual (Contextual Teaching and Learning) merupakan konsep belajar yang membantu guru mengaitkan antara materi yang diajarkannya dengan situasi dunia nyata siswa dan mendorong siswa membuat hubungan antara pengetahuan yang dimilikinya dengan penerapannya dalam kehidupan mereka sebagai anggota keluarga dan masyarakat.

Guru jarang sekali diikutkan dalam kegiatan pelatihan terkait dengan pendidikan inklusif, khususnya tentang pembelajaran tunarungu. Hanya 1 responden yang sudah pernah mengikuti pelatihan namun menurut responden pelatihan tersebut hanya menggunakan metode ceramah saja tanpa ada praktiknya.

Dengan tidak pernah mengikuti pelatihan terkait pengembangan diri dalam peningkatan kualitas pembelajaran, mengakibatkan guru-guru di sekolah inklusif tidak memiliki kompetensi yang seharusnya dimiliki oleh guru yang di kelasnya terdapat siswa tunarungu. Sehingga hasil belajar siswa tunarungu belum sesuai dengan harapan orangtua dan tujuan pendidikan nasional yang diamanatkan dalam Undang-undang nomor 20 tahun 2003 tentang sistem pendidikan nasional bahwa setiap warga Negara berhak mendapatkan pendidikan yang bermutu.

\section{PENUTUP}

\section{Kesimpulan}

Berdasarkan pembahasan penelitian yang telah diuraikan, maka kesimpulan dalam penilitian ini adalah sebagai berikut: Kompetensi guru reguler di sekolah inklusif dalam aspek menguasai karakteristik siswa belum dimiliki, guru mengenal karakteristik siswa tunarungu hanya berdasarkan subjektvitas tanpa dibekali pengetahuan dan keterampilan yang benar. Guru reguler juga belum mampu melakukan identifikasi kebutuhan bagi siswa-siswa di kelasnya sehingga pembelajaran yang dilakukan hanya bersifat umum dengan metode yang tidak bervariasi sehingga tidak mampu mengembangkan kemampuan siswa secara optimal.

Kompetensi guru dalam mengembangkan kurikulum yang diwujudkan dalam bentuk silabus dan RPP sudah cukup memadai. Namun untuk mengembangkan komponen-komponen kurikulum untuk siswa tunarungu dan siswa berkebutuhan khusus lainnya guru belum mampu dan tidak memiliki pengetahuan dalam menyusun PPI. Sehingga materi pelajaran, metode dan media serta evaluasi yang diberikan belum sesuai dengan kebutuhan dan kemampuan untuk siswa tunarungu dan siswa berkebutuhan khusus. 
Kompetensi guru dalam memanfatkan dan menggunakan TIK juga belum dimiliki, sehingga pembelajaran yang terjadi di kelas kurang menyenangkan, siswa tidak aktif dan kreatif cenderung mengikuti apa yang diberikan oleh guru.

Guru tidak pernah mengikuti pelatihan-pelatihan yang dapat meningkatkan kompetensi dalam pelaksanaan pembelajaran untuk siswa tunarungu, dan pelatihan yang ada selama ini belum dapat mengembangkan kemampuan guru secara signifikan karena tidak didukung dengan praktik dan sesuai dengan kondisi yang sebenarnya dihadapi oleh guru di sekolah inklusif.

\section{DAFTAR PUSTAKA}

Standar Nasional Pendidikan, Peraturan Pemerintah Nomor 19 Tahun 2005. Bandung: Fokusmedia, 2005.

Sagala, Saiful. Konsep dan Makna Pembelajaran. Bandung: Alfabeta, 2005

Tarmansyah. Inklusi: Pendidikan untuk Semua. Jakarta: Dirjen Dikti, Depdiknas, 2007.

Usman, Uzer. Menjadi Guru Profesional. Bandung: Remaja Rosdakarya, 2009.

Winarsih, Murni. Intervensi Dini Tunarungu Dalam Pemerolehan Bahasa. Jakarta: Dirjen Dikti, Depdiknas, 2007 